\title{
Studies on the expression of intestinal lactase in different individuals
} C B Harvey, Y Wang, L A Hughes, D M Swallow, W P Thurrell, V R Sams, R Barton,
S Lanzon-Miller, M Sarner
This variation in phenotype has been shown to be genetically determined, by using lactose tolerance tests on families ${ }^{3-7}$ but, despite the cloning and characterisation of the lactase gene, ${ }^{8-10}$ its precise molecular basis is unknown. There are differing reports about the levels of lactase mRNA in persistent and non-persistent individuals: some studies reported low lactase mRNA and low lactase protein ${ }^{11}$ whereas others claimed heterogeneity in the mRNA level in lactase non-persistent individuals. ${ }^{12}$ Abnormal processing of the lactase protein has been observed in a few lactase non-persistent individuals ${ }^{13} 14$ but it is not known whether these individuals had high or low mRNA.

This study was initiated because of these major discrepancies in the published reports which were difficult to evaluate. Because of the difficulty of obtaining material from healthy adults, we have used biopsy samples from patients undergoing diagnostic endoscopy but focused our study on samples with normal villous architecture. Furthermore, we have used a highly sensitive semiquantitative polymerase chain reaction (PCR) method for the detection of the mRNA which has meant that it was possible to examine both the lactase protein and mRNA in the same tiny samples.

Lactase, the enzyme responsible for hydrolysis of the milk sugar lactose, is expressed specifically in the enterocytes of the small intestine. Lactase activity declines after weaning in most of the world's people, a condition which is sometimes known as adult type hypolactasia, but in certain populations lactase may persist into adult life. It has been known for some time that these phenotypes occur at differing frequencies in different populations of the world. ${ }^{1}$ For example, the frequencies vary in different African tribes; most people in Thailand are lactase nonpersistent; and in Europe and India there tends to be a north-south gradient with lactase persistence more prevalent in the north. ${ }^{2}$

Accepted for publication 12 April 1994

The sequence of the oligonucleotide primers used in the polymerase chain reaction

\begin{tabular}{lll}
\hline Gene & Position in cDNA & Sequence 5'-3' \\
\hline LPH & $5454-546$ & TAC ACT GAC CCT TCT CTG CCA AG \\
SI & $5741-5763$ & GGC TTC GTT GTG TTT TCC CTT GC \\
& $8-30$ & GCA GCC TTA TCC AAG TCT GGT AC \\
DPP IV & $203-224$ & AGT CAC ACG AGT AGT AGC TGG AG \\
GAPHD & $1007-79$ & CCT TCT ACT CTG ATG AGT CAC TGC \\
& $77-100$ & GTC CCA CTA AGC AGT TCC ATC TTC \\
& $362-384$ & TCG GAG TCA ACG GAT TTG GTC GTA \\
\end{tabular}

LPH=lactase phlorizin hydrolase, $\mathrm{SI}=$ sucrase-isomaltase $\mathrm{DPP} \mathrm{IV}=$ dipeptidyl peptidase IV, and GAPDH = glyceraldehyde 3-phosphate dehydrogenase.

\section{Methods}

\section{PATIENTS}

Patients were selected for inclusion in the study from those who presented for routine endoscopy at the Gastroenterology Units of University College Hospitals and were being investigated for symptoms other than lactose intolerance. The patients (age range 21-83 years) were classified as to their ethnic origin using the medical record data. Ethical Committee approval was obtained for this study.

All biopsy specimens were taken from the distal duodenum. Thirty one samples were obtained by Crosby capsule and were divided immediately into two. In 30 cases multiple pinch samples were taken. A portion of the material was fixed in formal saline at room temperature, routinely processed, embedded in paraffin wax, stained with haematoxylin and eosin, and also stained immunohistologically for sucrase-isomaltase and alkaline phosphatase. The remainder was flash frozen in liquid nitrogen and stored at $-70^{\circ} \mathrm{C}$ for subsequent enzyme assay, protein or mRNA analysis. Because of subtleties of the fixation requirements for lactase protein detection, it 


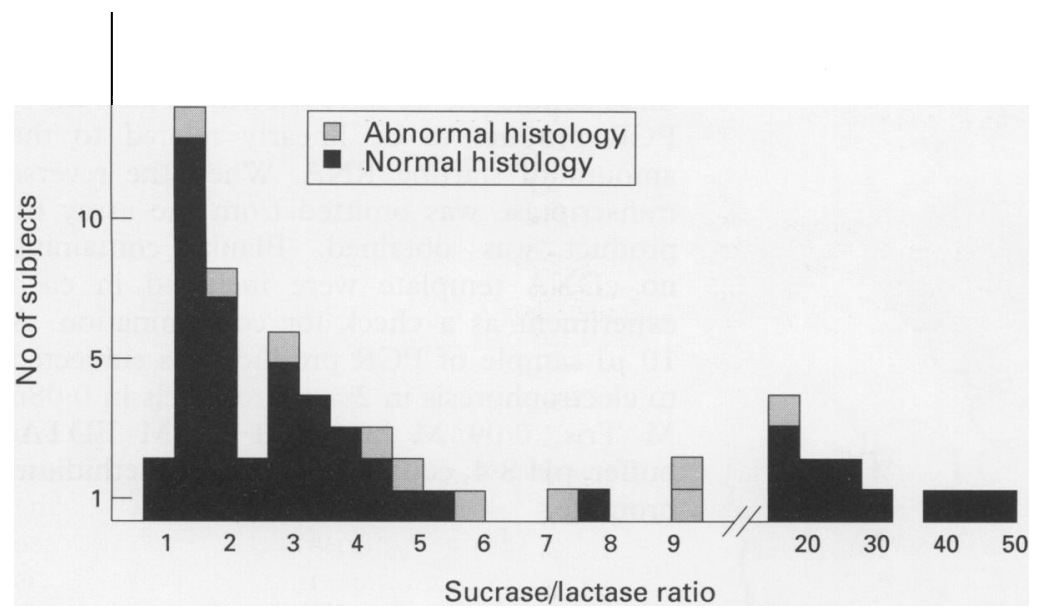

Figure 1: Distribution of the ratios of sucrase to lactase activity in the full series of patients tested.

turned out that different fixation and processing was required. Thus, in the last consecutive 21 cases, one further pinch biopsy was fixed at $4^{\circ} \mathrm{C}$ in $4 \%$ paraformaldehyde in phosphate buffered saline overnight, routinely processed, and embedded in paraffin wax to use for lactase immunohistology.

\section{IMMUNOHISTOLOGY}

Immunohistological detection of the brush border enzymes, alkaline phosphatase and sucrase-isomaltase, was carried out as a measure of functional integrity of the villi and was performed using the antibodies $\mathrm{AAPI}^{15}$ for alkaline phosphatase and $\mathrm{HBB} 3 / 705 / 60^{16}$ which

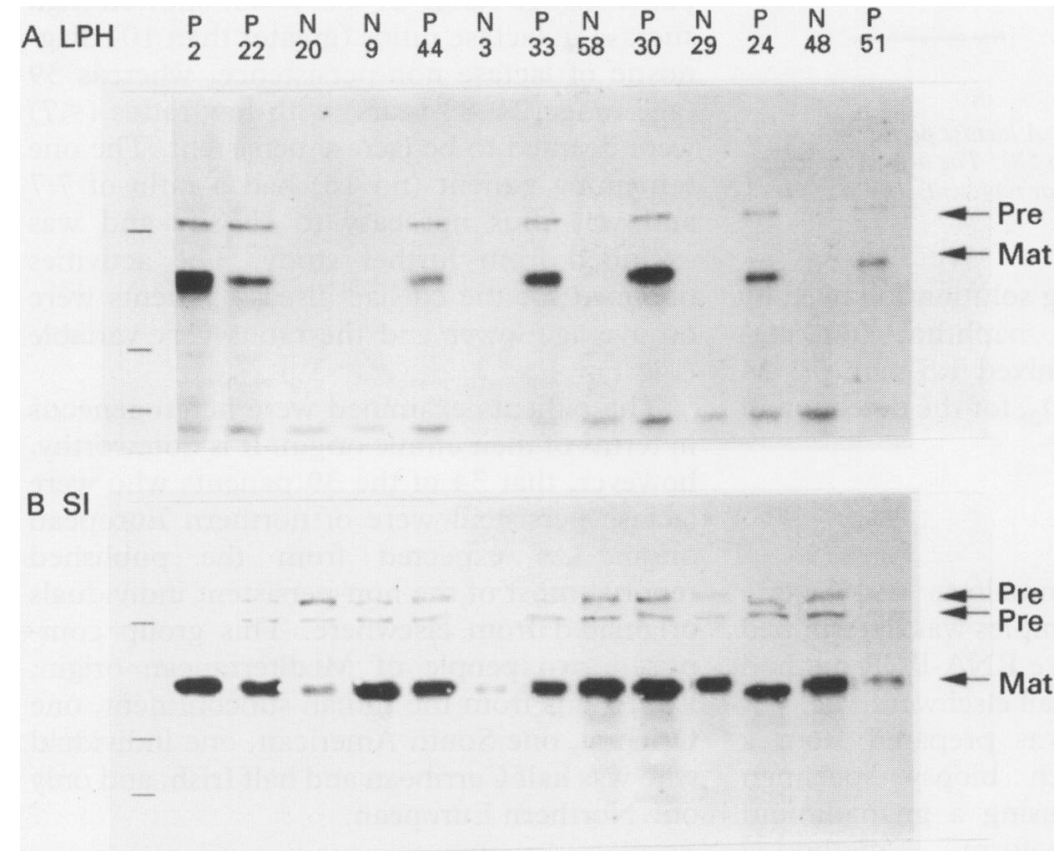

Figure 2: SDS-polyacrylamide gel electrophoresis and immunoblotting of 13 representative samples with normal histology. Individuals nos 20,9,3,58,29, and 48 are lactase non-persistent $(N)$ and the others (nos 2, 22, 44, 33, 30, 24, and 51) are lactase persistent (P). (a) Lactase (LPH); (b) sucrase-isomaltase (SI). The positions of the molecular weight markers $200 \mathrm{~K}, 97.4 \mathrm{~K}$, and $69 \mathrm{~K}$ are shown to the left of the gel photograph. The arrows on the right show the positions of the precursor polypeptides (Pre) and the mature polypeptides (Mat). The identity of the band of apparent molecular weight $65 \mathrm{~K}$ present on the lactase gel is unknown but is apparently due to a non-specific interaction of the mlac 10 antibody. Note that the layout of the two gels is identical and that for each individual $40 \mu \mathrm{l}$ of the same homogenate was loaded. recognises the isomaltase subunit of sucraseisomaltase. Immunohistology of lactase was carried out using the antibody, mlac $4 .^{17}$

The first antibody was an appropriately diluted culture supernatant and the bound antibody was detected using a standard streptavidin/biotin procedure. The sections were pretreated with $0.004 \%$ protease XXIV (Sigma) for 20 minutes before application of mlac 4 and $0 \cdot 1 \%$ trypsin for 10 minutes before application of AAPI. Standard positive and negative controls were used and the slides were independently assessed by more than one observer.

\section{ENZYME ASSAY}

Lactase and sucrase-isomaltase activities were measured by the 'Dahlqvist method' as adapted by Phillips et al ${ }^{18}$ on 1:80 (tissue: water, w/v) homogenates prepared from approximately $5 \mathrm{mg}$ of tissue (equivalent to one pinch biopsy).

The amount of glucose produced was determined colorimetrically and the activities were expressed as $\mu \mathrm{mol}$ of substrate cleaved $/ \mathrm{min} / \mathrm{g}$ wet weight of tissue. The assays were performed in batches, in duplicate, together with blanks without substrate and standard controls. Specific activities were not determined because of the limited amount of material available. Instead, results were expressed as a ratio of sucrase to lactase activity which has previously been shown to provide the best discrimination of lactase persistent and non-persistent individuals both in jejunum ${ }^{1719}$ and duodenum. ${ }^{20}$

\section{SDS-POLYACRYLAMIDE GEL ELECTROPHORESIS (PAGE)}

The remainder of the homogenates prepared for enzyme assay were stored at $-70^{\circ} \mathrm{C}$ before analysis by SDS-PAGE. Gradient gels of $5-15 \%$ acrylamide were used under standard conditions. ${ }^{21}$

The samples were mixed 1:1 with loading buffer containing 2-mercaptoethanol and boiled for three minutes before loading onto the gel. Rainbow molecular weight markers (from Bio-Rad) were used as mobility standards. The electrophoresis was carried out with voltage and current set to limit at $180 \mathrm{v}$ and $45 \mathrm{~mA}$ per gel respectively, using a Consort E443 power pack (Flowgen). The gels were electroblotted into nitrocellulose membrane (Schleicher \& Schuell) using a Bio-Rad Trans-Blot cell, in 25 $\mathrm{mM}$ Tris, $192 \mathrm{mM}$ glycine, $20 \%$ methanol at $34 \mathrm{v}, 130 \mathrm{~mA}$ for 16-18 hours.

The proteins were detected using the monoclonal antibodies: mlac 10 for lactase ${ }^{17}$ or HBB3/705/60 for the isomaltase subunit of sucrase-isomaltase. ${ }^{16}$ Filters were blocked with $3 \%$ bovine serum albumin in phosphate buffered saline, then incubated with the primary antibody. HBB3/705/60 culture supernatant was used neat, whereas mlac 10 was diluted 1 in 15 in the blocking solution. The primary antibody was detected using peroxidase conjugated, rabbit anti-mouse IgG 


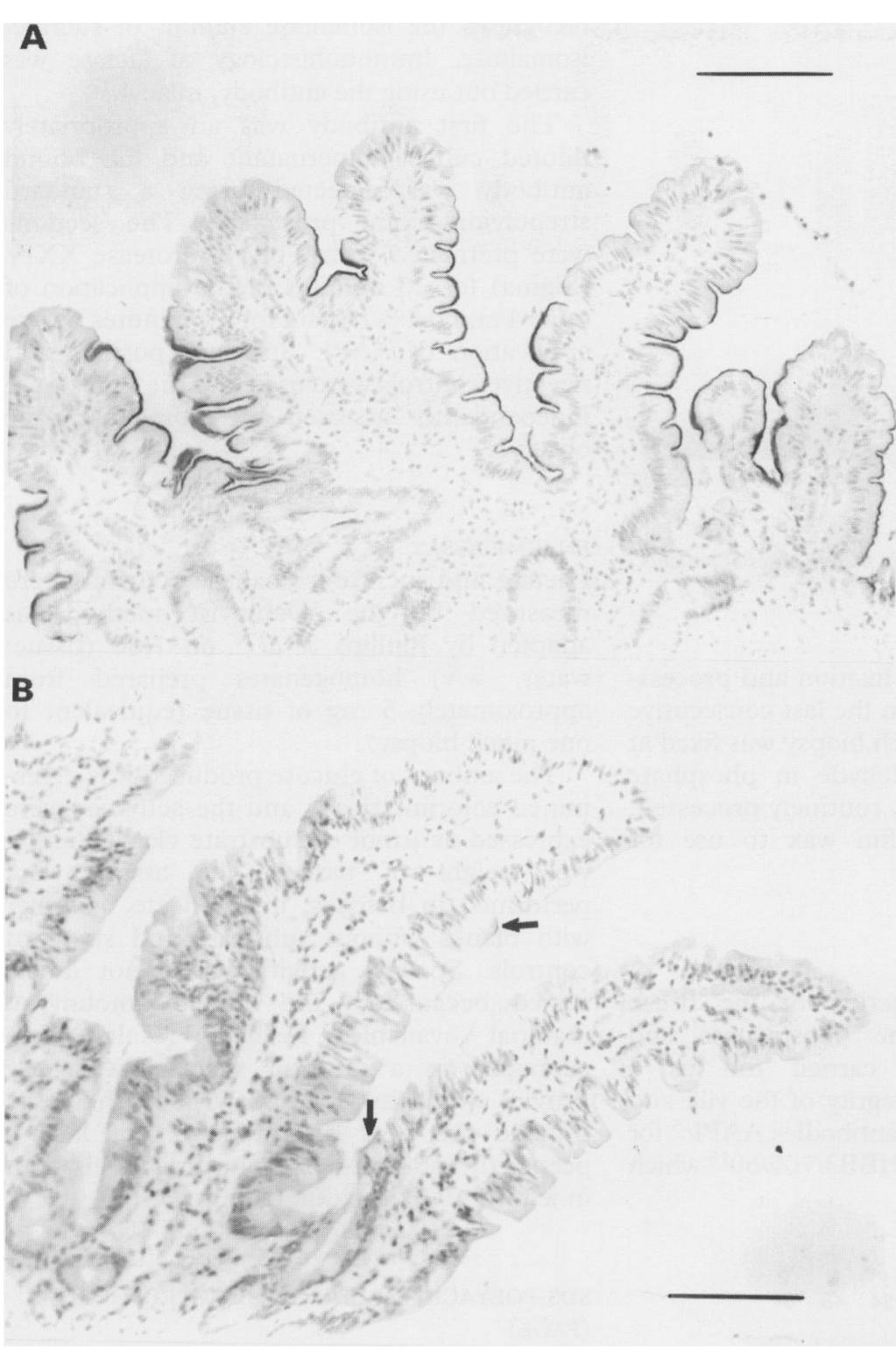

Figure 3: Examples of the lactase immunohistology results. $(A)$ A lactase persistent individual (no 45); (B) a lactase non-persistent individual (no 58). The arrows indicate patches of cells showing faint brush border staining. The scale bar represents $100 \mu$.

diluted 1:500 in blocking solution followed by the use of 4-chloro-1 naphthol (60 mg) dissolved in methanol, mixed 1:5 with $0 \cdot 1 \mathrm{M}$ Tris $\mathrm{pH} 8,0.0045 \% \mathrm{H}_{2} \mathrm{O}_{2}$, for the detection of peroxidase activity.

MRNA ANALYSIS

The level of sucrase-isomaltase and lactase mRNA present in the samples was determined using the semiquantitative RNA-PCR method which is described in detail elsehwere. ${ }^{22}$

Briefly, total RNA was prepared from a frozen portion of each biopsy specimen (approximately $5 \mathrm{mg}$ ) using a guanadinium thiocyanate-phenol-chloroform method. ${ }^{23}$ Reverse transcription of $2 \mu \mathrm{g}$ RNA was primed using random primers and cDNA corresponding to $0.5 \mu \mathrm{g}$ RNA was used for PCR. The oligonucleotides used for the PCR were synthesised using published sequence ${ }^{82-26}$ as shown in the Table. The PCR amplification in each case comprised 25 cycles of denaturation at $94^{\circ} \mathrm{C}$ for 30 seconds, annealing at $52^{\circ} \mathrm{C}$ for
40 seconds, and extension at $70^{\circ} \mathrm{C}$ for 60 seconds on a Hybaid Thermal Cycler. Under these conditions we have shown the amount of PCR product to be linearly related to the amount of starting RNA. When the reverse transcriptase was omitted from the assay no product was obtained. Blanks containing no cDNA template were included in each experiment as a check for contamination. A $10 \mu \mathrm{l}$ sample of PCR product was subjected to electrophoresis in $2 \%$ agarose gels in 0.086 $M$ Tris, $0.09 \mathrm{M}$ borate, $1.9 \mathrm{mM}$ EDTA, buffer, $\mathrm{pH} 8 \cdot 4$, containing $0 \cdot 1 \mathrm{mg} / \mathrm{ml}$ ethidium bromide.

\section{Results}

Sixty one patients were analysed in this survey, 51 of whom showed normal villous architecture. Normal brush border staining of alkaline phosphatase and sucrase-isomaltase was detected in all these cases, with most intense staining of the sides of the villi (data not shown). Ten samples showed abnormal histology, and comprised eight patients with coeliac disease and two of unknown diagnosis.

\section{ENZYME ACTIVITIES}

The results are shown as a ratio of sucrase to lactase activity (Fig 1). There was no difference in the ranges of the enzyme activities or their ratios obtained using either of the two types of biopsy, Crosby capsule or multiple pinch, and the data were therefore pooled. The ratios obtained for the individuals showing normal villous architecture (shaded in Fig 1) fall into two major groups. Eleven of the patients (age range 27-82 years) showed high sucrase to lactase ratios (greater than 10) diagnostic of lactase non-persistence, whereas 39 (age range $21-83$ years) with low ratios $(<7)$ were deemed to be lactase persistent. The one remaining patient (no 16) had a ratio of $7 \cdot 7$ and was thus not easy to classify and was excluded from further study. The activities obtained for the coeliac disease patients were on average lower and the ratios very variable (Fig 1).

The patients examined were heterogeneous in terms of their ethnic origin. It is noteworthy, however, that 34 of the 39 patients who were lactase persistent were of northern European origin. As expected from the published reports, most of the non-persistent individuals originated from elsewhere. This group comprised two people of Mediterranean origin, five Asians from the Indian subcontinent, one Oriental, one South American, one individual who was half Carribean and half Irish, and only one Northern European.

\section{ANALYSIS OF THE LACTASE PROTEIN BY} SDS-PAGE

The lactase protein was readily detectable in the samples from all 35 persistent individuals tested (Fig 2). A major band of apparent molecular weight 145000 , corresponding to the mature lactase polypeptide, and a minor 

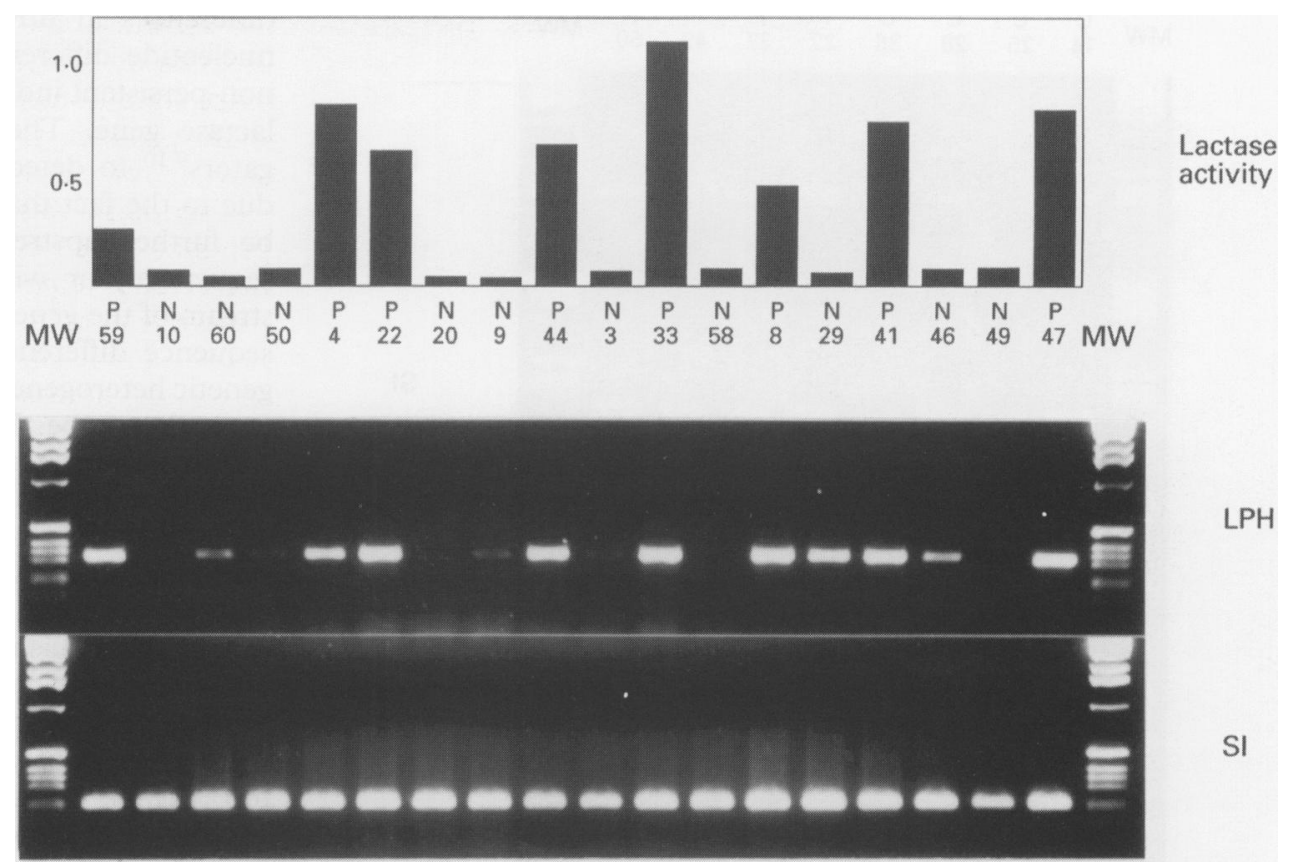

Figure 4: RNA-PCR of the 10 lactase non-persistent samples tested and eight representative lactase persistent samples in comparison with the enzyme activities measured in the same individuals. (A) Bar chart of lactase activities expressed as a ratio of lactase to sucrase, (B) lactase $R N A-P C R$ product (LPH), (C) sucrase-isomaltase RNA-PCR product (SI), visualised with ethidium bromide after electrophoresis on agarose gels. $P$ denotes lactase persistent; $N$ denote lactase non-persistent. The track denoted MW contains the $1 \mathrm{~Kb}$ ladder (BRL) molecular weight markers. Samples are identified using the series number of the individual and are all samples which showed normal histology.

band of apparent molecular weight 225000 due to a precursor form were detected in each case. Neither of these bands was detected, or was present in only trace amounts, in the 11 lactase non-persistent individuals, although the sucrase-isomaltase protein was detectable as usual, as the mature isomaltase polypeptide, apparent molecular weight 130000 and two precursor forms 230000 and 260000 ) (Fig 2). In one of the non-persistent individuals (no 46) the residual lactase protein showed clear evidence of an abnormal pattern which included some additional very faint higher molecular weight bands (data not shown). In patients with coeliac disease, lactase protein was detected in three individuals (no 14, 15, and 37), a weaker staining lactase band was seen in another three individuals (no 28, 31, and 36) and neither lactase nor sucraseisomaltase was detected in one individual (no 25) (data not shown).

\section{LACTASE IMMUNOHISTOLOGY}

Twenty one samples (15 persistent and six non-persistent) were also examined immunohistologically for lactase protein. Positive staining was detected on the brush border of most of the enterocytes of all 15 persistent individuals tested, with the most intense staining on the sides of the villi (Fig 3A). In contrast, the vase majority of cells were negative in the non-persistent individuals and only very occasional cells stained very faintly (Fig 3B).

MESSENGER RNA STUDIES

The levels of sucrase-isomaltase mRNA were reasonably constant in all the histologically normal individuals tested (Fig 4). Lactase mRNA, on the other hand, in the same individuals, was much more variable. High levels were detected in all the 35 persistent individuals tested and in one of the non-persistent individuals (no 29 in Fig 4). In all the other nine non-persistent cases tested, the level of lactase mRNA was low. It is noteworthy that the lactase protein was not detected in the non-persistent individual with high mRNA (Fig 2) and that this individual showed normal expression of sucrase-isomaltase and alkaline phosphatase as determined by immunohistology.

The levels of lactase and sucrase-isomaltase mRNA were determined in five of the biopsy samples from the patients suffering from coeliac disease. The levels of mRNA coding for the brush-border enzyme dipeptidyl peptidase IV (DPP IV) were also examined in these cases, and compared with 15 of the individuals with normal villous architecture. In one case (no 14), all three mRNA levels were normal. In two cases (nos 25 and 36) lactase mRNA was greatly reduced, while sucrase-isomaltase and DPP IV mRNAs were decreased to a lesser extent. In the other two cases (nos 1 and 28), lactase mRNA was reduced, but the levels of sucraseisomaltase and DPP IV were unaffected. Representative results are shown in Figure 5.

\section{Discussion}

We have shown that the lower enzyme activity in lactase non-persistent adults is associated, in nine of 10 cases, with a lower amount of lactase mRNA and consequent absence or lower amount of the lactase protein.

The low level of lactase mRNA in most nonpersistent individuals suggests that a depressed rate of transcription of the lactase gene or 


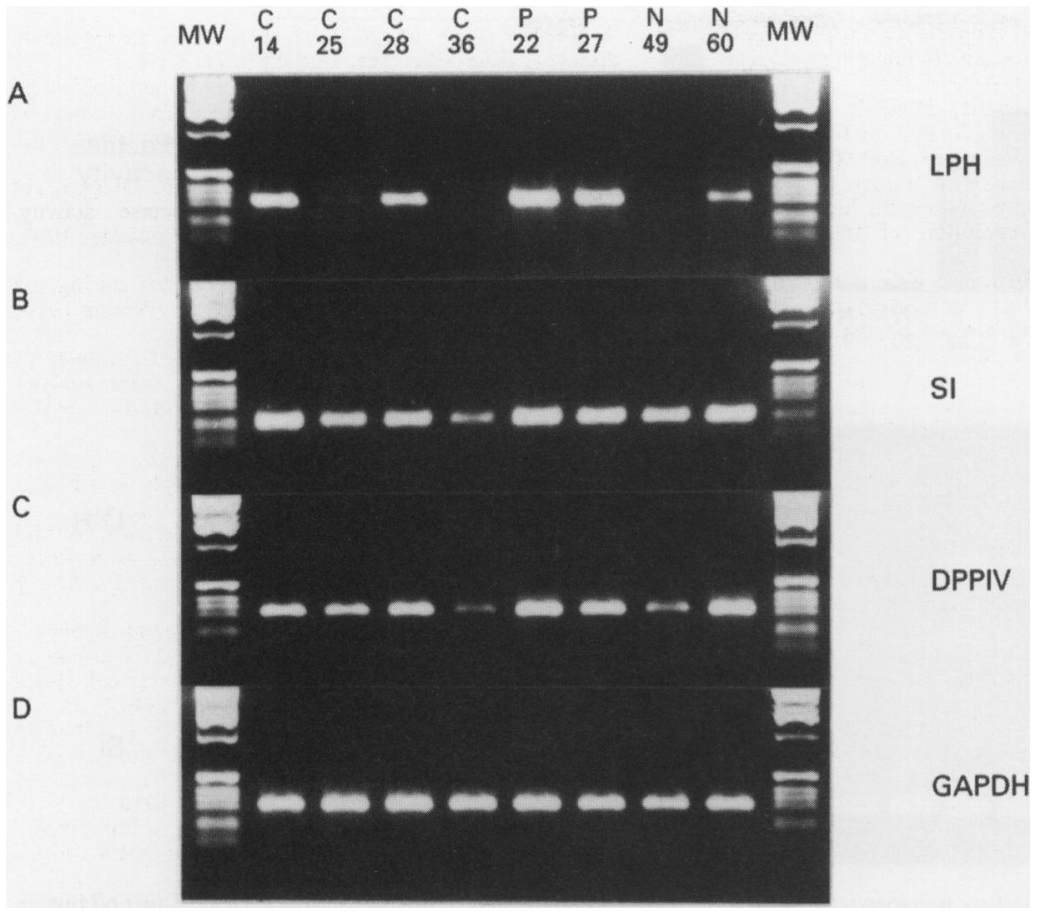

Figure 5: RNA-PCR analysis of samples from four coeliac disease patients and four controls with normal histology. RNA-PCR products visualised with ethidium bromide after electrophoresis on agarose gels. (A) Lactase RNA-PCR product $(L P H),(B)$ sucrase-isomaltase $R N A-P C R$ product $(S I),(C)$ dipeptidylpeptidase IV RNA-PCR product (DPP IV), and (D) glyceraldehyde 3-phosphate dehydrogenase RNA-PCR product (GAPDH). The track denoted MW contains the $1 \mathrm{~Kb}$ ladder molecular weight markers. Nos 14, 25, 28, and 36 are individuals with coeliac disease $(C)$. The controls consist of two lactase persistent ( $P$, nos 22 and 27) and two lactase non-persistent individuals $(N$, nos 49 and 60$)$.

decreased mRNA stability is responsible for the low lactase activity in nine of the 10 lactase nonpersistent individuals. This decrease in steady state level of lactase mRNA seems to result in the reduced synthesis of the lactase protein.

Our studies are thus in broad agreement with those of Escher et $a l,{ }^{11}$ and are supported by the very recent findings of Fajardo et al $^{27}$ and suggest that differences in post-translational processing of the protein are not directly responsible for person to person differences in lactase activity. The only individual in whom we showed any evidence of an abnormal protein pattern also had low lactase mRNA. However, it is of particular interest that we, like Sebastio et al ${ }^{12}$ in their study of a Neapolitan population, have also found a non-persistent individual with high mRNA. Curiously, this individual is also an Italian.

Although the available evidence tends to suggest that lactase non-persistence is heterogeneous, it is important to consider the possibility that the heterogeneity may not be genetically determined but a result of local environmental influences in the gut. Maiuri et al ${ }^{28}$ have recently shown that even within a single villus from a single hypolactasic individual there is a heterogeneous population of cells with respect to the expression of lactase mRNA and protein. In our study it was not possible to analyse the lactase protein immunohistologically in the non-persistent individual with high RNA (no 29), as paraformaldehyde fixed material was not available. However, it is noteworthy that the lactase protein was not detectable by SDS-PAGE (Fig 2).

The most probable genetic cause of the differences in mRNA level is that there are nucleotide differences between persistent and non-persistent individuals within or around the lactase gene. The failure by several investigators ${ }^{9} 10$ to detect such differences could be due to the fact that the relevant region(s) may be further upstream than the $1 \mathrm{~kb}$ already sequenced, or within the introns, or downstream of the gene. It could also be that critical sequence differences were overlooked due to genetic heterogeneity of the lactase non-persistence phenotype. However, genetic differences within a trans-acting factor such as a DNA binding protein which recognises critical promotor sequences, have not yet formally been excluded. We are currently using the material collected during the course of this project to distinguish between these possibilities.

Our previous studies have indicated that lactase persistent heterozygotes have intermediate levels of lactase activity. ${ }^{19}$ In this study too (Fig 1), the lactase persistent group show suggestive evidence of a bimodal distribution consistent with group of homozygotes and a group of heterozygotes. We are currently adapting the RNA-PCR procedure to determine whether these groups also differ in the level of lactase mRNA as would be expected for a cis-acting (as opposed to trans-acting) regulatory element.

Another aspect of this study is our preliminary observations on the samples taken from the patients with coeliac disease. It had previously been shown that the activity of different brush border enzymes is affected selectively in patients suffering from coeliac disease, ${ }^{29} 30$ the activity of lactase being reduced significantly, with DPP IV being less affected. It is thus of some interest that this study indicates that the mRNA levels may also to be affected selectively.

The normal expression of brush-border hydrolases depends on the relative rates of synthesis, transport, and turnover of the mRNAs and their protein products as well as the cell kinetics. In the case of lactase, the expression of the mRNA also depends on the genetic constitution of the individual, namely their lactase persistence status. Elucidation of the molecular basis of the lactase persistence polymorphism will eventually enable the distinction between primary and secondary lactase deficiency.

We would like to thank members of the Gastroenterology Units of University College Hospitals, in particular Drs R Loke, and S McCartney for their help in obtaining the samples. We would also like to thank the Directors lab at the Imperial Cancer Research Fund for supplying the monoclonal antibody AAPI, Dr H-P Hauri for $3 / 705 / 60$, Dr D Darmoul for the GAPDH primers, and Dr L Mauiri for helpful advice. CBH is supported on a MRC Human Genome Mapping Project studentship.

A preliminary version of this work was presented in abstract form in the British Society of Gastroenterology meeting, March 1993.

1 Cook GC, Kajubi SK. Tribal incidence of lactase deficiency in Uganda. Lancet 1966; i: 725-9.

2 Flatz G. Genetics of lactose digestion in humans. Adv Hum Genet 1987; 16: 1-77.

3 Gilat $T$, Benaroya $Y$, Gehman-Malachi $E$, Adam A Genetics of primary adult lactase defiency. Gastroenterology 1973; 64: 562-8.

4 Sahi T. The inheritance of selective adult-type lactose malabsorption. Scand f Gastroenterology 1974; 9: 1-73. 5 Lisker R, Gonzalez B, Daltabuit M. Recessive inheritance of the adult type of intestinal lactase deficiency. Am $\mathcal{F}$ Hum Genet 1975; 27: 662-4. 
6 Ransome-Kuti O, Ketchmer N, Johnson JD, Gribble JT. A genetic study of lactose digestion in Nigerian families. Gastroenterology 1975; 68: 431-6.

7 Swallow DM, Harvey CB. Genetics of adult-type hypolactasia. Dynamic Nutrition Research 1993; 3: 1-7.

8 Mantei N, Villa M, Enzler T, Wacker H, Boll W, James P, et al. Complete primary structure of human and rabbit lactase-phlorizin hydrolase: implications for biosynthesis, membrane anchoring and evolution of the enzyme. $E M B O \mathcal{F} 1988 ; 7: 2705-13$.

9 Boll W, Wanger P, Mantei N. Structure of the chromosomal gene and cDNAs coding for lactase phlorizin hydrolase in humans with adult-type hypolactasia or persistence of lactase. Am ₹ Hum Genet 1991; 48: 889-902.

10 Lloyd M, Mevissen G, Fischer M, Olsen W, Goodspeed D, Genini $M$, et al. Regulation of intestinal lactase in adult hypolactasia. F Clin Invest 1992; 89: 524-9.

11 Escher JC, de Koning ND, van Engen CGJ, Arora S, Buller HA, Montgomery RK, Grand RJ. Molecular basis of lactase levels in adult humans. 7 Clin Invest 1992; 89: lactase

12 Sebastio G, Villa M, Sartorio R, Guzzetta V, Poggi V, Auricchio $\mathrm{S}$, et al. Control of lactase in human adult-type hypolactasia and in weaning rabbits and rats. Am $\mathcal{F} \mathrm{Hum}$ Genet 1989; 45: 489-97.

13 Witte J, Lloyd M, Lorenzsonn V, Korsmo H, Olsen W. The biosynthetic basis of adult lactase deficiency. $\mathcal{F}$ Clin Invest 1990; 86: 1338-42.

14 Rossi M, Maiuri L, Fusco MI, Danielsen EM, Auricchio S. The human adult-type hypolactasia is a heterogeneous condition in in vitro biosynthetic studies. Dymamic Nutrition Research 1993; 3: 174-87.

15 Arklie J, Trowsdale J, Bodmer WF. A monoclonal antibody to intestinal alkaline phosphatase made against body to intestinal alkaline phosphatase made against 303-12.

16 Hauri H-P, Roth J, Sterchi EE, Lentze MJ. Transport to cell surface of intestinal sucrase-isomaltase is blocked in the Golgi aparatus in a patient with congenital sucraseisomaltase deficiency. Proc Natl Acad Sci USA 1985; 82: 4423-7.

17 Maiuri L, Raia V, Potter J, Swallow D, Ho M-W, Fiocca R, et al. Mosaic pattern of lactase expression by villous enterocytes in human adult-type hypolactasia. Gastroenterology 1991; 100: 359-69.

18 Phillips AD, Avigad S, Sacks J, Rice SJ, France NE,
Walker-Smith JA. Microvillous surface area in secondary disaccharidase deficiency. Gut 1980; 21: 44-8.

19 Ho M-W, Povey S, Swallow D. Lactas polymorphism in adult british natives: estimating allele frequencies by enzyme assays in autopsy samples. Am 7 Hum Genet 1982; 34: $650-7$.

20 Lember M, Tamm A, Maaroos H, Suurmaa K. Diagnosis of primary hypolactasia by duodenal lactase activity. European fournal of Gastroenterology and Hepatology 1993; 5: $511-3$.

21 Laemmli UK. Cleavage of structural proteins during the assembly of the head of bacteriophage T4. Nature 1970; 227: $680-5$.

22 Wang Y, Harvey C, Rousset M, Swallow D. Expression of intestinal mRNA transcripts during development: analysis by a semi-quantitative RNA PCR method. Pediatr Res 1994; 36: (in press).

23 Chomczynski P, Sacchi N. Single-step method of RNA isolation by acid guanidinium thiocyanate-phenol-chloroform extraction. Anal Biochem 1987; 162: 156-9.

24 Chantret I, Lacasa M. Chevalier G, Ruf J, Islam I, Mantei $\mathrm{N}$, et al. Sequence of the complete CDNA and the $5^{\prime}$ structure of the human sucrase-isomaltase gene. Biochem $f$ ture of the human

25 Darmoul D, Lacasa M, Baricault L, Marguet D, Sapin C, Trotot $\mathrm{P}$, et al. Dipeptidyl peptidase IV (CD26) gene expression in enterocyte-like colon cancer cell lines HT-29 and Caco-2. F Biol Chem 1992; 267: 4824-33.

26 Tokunaga K, Nakamura Y, Sakata K, Fujimori K, Ohkubo $M$, Sawada K, Sakiyama S. Enhanced expression of a glyceraldehyde-3-phosphate dehydrogenase gene in human lung cancers. Cancer Res 1987; 47: 5616-9.

27 Fajardo O, Naim HY, Lacey SW. The polymorphic expression of lactase in adults is regulated at the mRNA level. sion of lactase in adults is regulated

28 Maiuri L, Rossi M, Raia V, Garipoli V, Swallow D, Hughes $\mathrm{L}$, Noren O, Auricchio S. Mosaic regulation of lactase in human adult-type hypolactasia. Gastroenterology 1994; 107: 54-60.

29 Phillips AD, Smith MW, Walker-Smith HA. Selective alteration of brush-border hydrolases in intestinal diseases in childhood. Clinical Science 1988; 74: 193-200.

30 Smith MW, Phillips AD. Abnormal expression of dipeptidylpeptidase IV activity in enterocyte brush-border membranes of children suffering from coeliac disease. Experimental Physiology 1990; 75: 613-6. 